\title{
EU MEMBERS MULTI-CRITERIA RANKING ACCORDING TO SELECTED TRAVEL INDUSTRY INDICATORS
}

\author{
Ivana Marjanović ${ }^{1}$ \\ Žarko Rađenović ${ }^{2}$ \\ Milan Marković ${ }^{3}$
}

DOI: https://doi.org/10.31410/tmt.2019.639

\begin{abstract}
As a multidimensional phenomenon that contributes to the economic growth and development of the country, tourism is an important sector for every national economy. Countries with developed tourism sector acquire more benefits than the countries with poorly developed or underdeveloped tourism. For assessment of the tourism development, multi-criteria decision-making techniques can be applied. In this paper, the tourism development of European Union (EU) Member States was analyzed based on selected travel and tourism industry indicators using Multi-Objective Optimization by Ratio Analysis (MOORA) and a new Additive Ratio Assessment (ARAS). The results indicate that Western and Southern European countries have the most developed tourism sector. Results also enable EU Member States to assess their relative position which might be of use to their policy makers.
\end{abstract}

Keywords: ENTROPY, Tourism Development Evaluation, MOORA, ARAS.

\section{INTRODUCTION}

$\mathrm{T}$ ourism is a global, both spatial and socio-economic phenomenon that encompasses various other aspects such as political, cultural, environmental, aesthetic, emotional. It can be said that there is almost no country in the world that does not develop tourism in some form. In the broadest sense tourism represents every form of people's movement outside their usual environment. According to the World Tourism Organization (2001) "tourism comprises the activities of persons traveling to and staying in places outside their usual environment for not more than one consecutive year for leisure, business and other purposes" (p. 13). Goeldner and Ritchie (2007) define tourism "as the processes, activities, and outcomes arising from the relationships and the interactions among tourists, tourism suppliers, host governments, host communities, and surrounding environments that are involved in the attracting and hosting of visitors" (p. 5).

On the other hand, tourism is a sector whose importance cannot be quantified precisely because it is linked to almost every aspect of society. It has a direct impact on various macroeconomic categories, wherein, one of the most important are multiplicative effects of tourism on the economy. Nevertheless, when considering the importance of tourism for a country, it is important to differentiate between domestic and foreign tourism consumption, because of the difference in the economic effects that result from them. Domestic tourism consumption is a redistribution of income earned in one economy, while foreign tourism consumption is a redirection of an income from one economy to another (under the condition that foreign tourists use local services and products), which directly influences economic growth. This spillover of national income from abroad to a particular tourist country has multiplier effects on the economy (Pratt, 2015).

\footnotetext{
$1 \quad$ Faculty of Economics, University of Niš, Trg kralja Aleksandra Ujedinitelja 11, Niš, Serbia

2 Innovation Centre of the University of Niš, Vojvode Tankosića 14/8, 18000 Niš, Serbia

3 Innovation Centre of the University of Niš, Univerzitetski trg 2, Niš, Serbia
} 
Clement (1961) was first to introduce the multiplicative effects of tourism, and he has shown that multiplier in Pacific and Far East countries amounts to 3.2 meaning that during a period of one year, one dollar of foreign tourists' disbursements multiplies to $\$ 3.2$ in the national economy. Favourable multiplier tourism effects were also presented by Pratt (2015). Various studies have reported evidence of the positive influence of tourism development on economic growth (Balaguer \& Cantavella-Jorda, 2002; Oh, 2005; Lee \& Chang, 2008; Pablo-Romero \& Molina, 2013; Brida et al., 2016). Several countries have based their development mainly on tourism. However, one of the basic preconditions for tourism developments is the existence of a favourable and stable political climate. Hence, tourism development is interlinked with the creation and maintenance of good relations between countries and regions, for mutual benefit. Along with strengthening of the economy, tourism has several other effects: it stimulates employment, influences job creation and balance of payments, and contributes to the improvement of the general standard of living. Besides direct effects, there are indirect effects related to the development of agriculture, industry, construction. The development of tourism as a highly labour-intensive activity can significantly increase employment and thus contribute to solving the unemployment problem, which is one of the burning problems of many economies today (Bošković, 2009). Tourism is considered as a significant single source of employment in the world and in 2018 the total contribution of travel and tourism to employment, including jobs indirectly supported by the industry was $10 \%$ of total employment (WTTC, 2019).

The impact of tourism on the national economy can be felt first through the country's balance of payments, thus some consider this as the most important economic function of tourism. Tourism is a very important source of foreign exchange for many countries. For countries that have primarily distinguished themselves as significant receptive tourism countries in the international tourism market, foreign exchange inflow from tourism is the most important item of income in the balance of payments and is an important factor for overall development of the economy (Bošković, 2009). As many countries in the world today face balance of payments deficits, international tourism can help alleviate such problems and contribute to providing the financial resources needed for economic and social development. This is the reason why most of them seek to stimulate the consumption of foreign tourists through active tourism policy. The fact is that for many countries, especially those with a limited industrial sector or with only a few opportunities to develop alternative export sectors, tourism is a major source of foreign exchange earnings.

One of the important aspects that should also be taken into consideration when the effects of tourism are considered is the direct linkage of tourism and the environment. Tourism develops and progresses within the environment, exploits and transforms it, but at the same time, it seeks to preserve and improve it. Consequently, tourism is particularly committed to the preservation and protection of the natural environment because tourism development is largely dependent on the natural environment (Tang, 2015). Nevertheless, despite positive influence on economic growth, tourism development may cause and in a number of cases creates environmental problems (Zhong, et al., 2011). In line with the new tendencies, further development of tourism should be based on the sustainable development of the tourism sector and other complementary activities. In this manner, tourism supports the introduction of green technologies and greater use of renewable energy sources, and, most importantly, raising the collective awareness of society about the importance of preserving the environment (Swarbrooke, 1999). 
Regarding multiple effects of tourism, the adequate assessment of the country's level of tourism development is a necessity. Therefore, the main aim of this paper is to evaluate European Union (EU) countries based on the tourism industry indicators using two multi-criteria decision-making techniques, MOORA and ARAS. Furthermore, sub-aim of the analysis is to inspect the existence of rank-inversion caused by the application of different techniques. To achieve stated aim the following hypothesis will be tested: The application of different multi-criteria decision-making techniques on the same dataset and with the same criteria weights doesn't lead to rank-inversion. The absence of rank-inversion in a situation where different multi-criteria methods are used will indicate the objectivity of the results obtained. Also, it will indicate that the decision-maker may choose a specific multi-criteria method, depending on his or her preferences and expertise, without compromising the objectivity of ranking.

The rest of the paper is structured as follows. After introductory notes, in the second section, a brief presentation of the main trends in the world's tourism development is offered. The third section gives a theoretical background of the tourism assessment, while in the fourth section methodology and data are presented. In the fifth section comparative analysis of results is given. Concluding remarks are offered in the sixth section.

\section{TRENDS IN TOURISM DEVELOPMENT IN THE WORLD}

Tourism represents a dynamic category that is constantly evolving. On the one hand, this development encompasses new forms of travel and new destinations, while on the other hand, it created a need for new forms of organization, new resources and strategies. According to UNWTO (2016), tourism has experienced continuous growth in the past six decades and is becoming the fastest growing economic sector in the world. International tourism is a significant part of the international economy. The tourism sector can be considered as one of the growth drivers of the world economy and among the largest export industries. It is the world's third-largest export category after chemicals and fuels. Exports from international tourism in 2018 comprised 7\% of global exports and $29 \%$ of the world's services exports (UNWTO, 2019a). Since 1950, when international travel becomes more accessible to the general public, the number of arrivals increased from 25 million to 278 million in 1980, then to 674 million in 2000 and to 1186 million in 2015 (UNWTO, 2016). International tourist arrivals grew 7.0\% year-over-year (yoy) in 2017, which is the highest increase since the 2009 global economic crisis and also above the long-term forecast of UNWTO of, on average, 3.8\% per year for the period 2010 to 2020 (UNWTO, 2018). In the previous period, there has been fluctuation in the growth and development of tourism in terms of declines and a return to the upward trend. In the coming years, international arrivals are expected to have an upward trend with the forecast that in 2030 international arrivals will amount to 1.8 billion (UNWTO, 2011).

Regarding the regional structure, Europe dominates with a share of $51 \%$, wherein $40.2 \%$ is a share of EU Member States, in the total international tourist arrivals in 2018, followed by Asia and the Pacific 25\%, the Americas 15\%, Africa 5\%, and the Middle East 4\% (UNWTO, 2019a). According to UNWTO (2019b):

- International tourist arrivals in Europe in 2018 increased by 6\% yoy compared to 2017. The highest growth was recorded by Southern and Mediterranean Europe (7\%) followed by Central and Eastern Europe (6\%) and Western Europe (6\%);

- International tourist arrivals in Asia and the Pacific in 2018 increased 6\% yoy compared to 2017, wherein the highest growth was recorded by South-East Asia (7\%), followed by North-East Asia (6\%) and South Asia (5\%) while Oceania exhibited growth at 3\%; 
- The Americas recorded growth of 3\% yoy, wherein the highest growth was obtained by North America (4\%), followed by South America (3\%), while Central America and the Caribbean recorded a decrease of $2 \%$;

- International tourist arrivals in Africa increased by 7\% yoy in 2018, with an increase of $10 \%$ in North Africa and 6\% in Sub-Saharan.

\section{THEORETICAL BACKGROUND OF TOURIST DESTINATIONS COMPETI- TIVENESS ASSESSMENT}

If growth and development were major priorities in the last decades, the forthcoming years will be marked by intense competition of destinations and the creation of new products and offers that will be appealing to tourists. The ability of tourist destination to transform its comparative advantages (both, inherited or generated) into tangible outcomes is the basis of competitiveness (Ritchie \& Crouch, 2003). The importance of this transformation for destinations is reflected in determining their competitive advantage and position relative to competitors (Niavis \& Tsiotas, 2019). With increasing competition between destinations over the last decades, the need to identify the competitive capabilities of the destination, as well as the strengths and weaknesses of its competitors, has increased (Pulido-Fernández \& Rodríguez-Díaz, 2016). There are various definitions of tourism destination competitiveness. Dwyer \& Kim (2003) consider tourist destination competitiveness as the comparative capability of a destination to satisfy the requirements of tourists in various aspects of the tourism experience or to provide products and services that outperform other destinations on those aspects of the tourism experience. OECD (2019) describes competitiveness as the capability of the destination to improve its desirability for residents and non-residents, to provide quality, innovative, and attractive tourism services to consumers and to acquire market shares on the domestic and global market places, while making sure that the existing resources supporting tourism are used efficiently and in a sustainable way. Several methodologies have been developed to measure the tourist competitiveness of a destination. To provide information regarding the relative position of each country in terms of tourism competitiveness, the World Economic Forum has started publishing The Travel \& Tourism Competitiveness Index since 2007 (WEF, 2019). The OECD has proposed Indicators for Measuring Competitiveness in Tourism (Dupeyras \& MacCallum, 2013), while the EU has created European Tourism Indicator System (ETIS, 2016). Many studies have applied various methodologies in the attempt to measure the competitiveness of a destination. Baggio (2019) offers a comprehensive review of different methods for the measurement of tourism. Among approaches of qualitative nature two main categories are distinguished (Pulido-Fernández \& Rodríguez-Díaz, 2016): i) approaches that utilize survey data related to opinions and perceptions of tourists (Bahar \& Kozak, 2007; Cracolici \& Nijkamp, 2009; Chen et al., 2011; Chen et al. 2016; Shi et al., 2008) and ii) approaches grounded on the empirical assessment of a set of subjective indicators of tourism competitiveness, via tourism stakeholder surveys (Yoon, 2002; Bornhorst et al., 2010; Dwyer et al., 2012; Poudel et al., 2016). Yet, one of the limitations of qualitative methods is that they are subjective, hence, other methods are proposed for the assessment of tourism destination competitiveness. There are several studies related to the application of quantitative data in the tourism assessment. A comprehensive review of frontier studies in tourism literature is presented by Assaf \& Josiassen (2016). Two leading methodologies within this research area used for the assessment of tourism development are data envelopment analysis (Cracolici \& Nijkamp, 2006; Cracolici et al., 2008; Barros et al. 2011; Cuccia et al., 2017; Niavis \& Tsiotas, 2019) and stochastic frontier analysis (Chen, 2007; Wang et al. 2007; Hu et al. 2010; Assaf, 2012). Among forecasting methods in tourism evaluation, the Delphi technique is often applied (Miller, 2001; Garrod \& Fyall, 2005; 
Choi \& Sirakaya, 2006). Regarding statistical approaches, principal component analysis and cluster analysis are often applied (Ryan \& Huyton, 2000; Spencer \& Holecek, 2007; Cracolici \& Nijkamp, 2009; Vareiro et al., 2013; Zaman et al., 2016).

Assessment of the country's tourism competitiveness implies consideration of multiple, often conflicting criteria. For that kind of decision problems, multi-criteria decision-making techniques are appropriate. Multi-criteria decision-making techniques are widely used for the creation of composite indicators. Composite indicators represent valuable tools for synthetization and monitoring of multidimensional phenomena (Mendola \& Volo, 2017). Additionally, composite indicators provide an easier interpretation of phenomena compared to searching of a common trend in numerous single indicators (Nardo et al., 2005). Building a composite indicator was considered in several studies (Fernández \& Rivero, 2009; Perez et al. 2013; Croes \& Kubickova, 2013; Blancas et al. 2015; Carrillo \& Jorge, 2017). Besides creation of the composite index, various multi-criteria techniques have been applied for the assessment and ranking according to tourism development: TOPSIS (Zhang et al. 2011; Huang \& Peng, 2012; Nilashi et al. 2019; Kwok \& Lau, 2019), AHP (Crouch \& Ritchie, 2005; Ghamgosar et al. 2011; Zhou et al., 2015), PROMETHEE (Lopes et al., 2018; Ostovare \& Shahraki, 2019), and ELECTRE (Del Vasto-Terrientes et al. 2015; Botti \& Peypoch, 2013).

Nevertheless, despite a large number of methodologies proposed, Mendola and Volo (2017) claim that the development of an adequate metric is limited by the fact that there is a wide variety of destinations and markets. Additionally, Baggio (2019) suggests a full integration between qualitative and quantitative approaches, which will lead to more comprehensive metrics.

\section{DATA AND METHODOLOGY}

The analysis of the state of tourism development in EU member countries was conducted using the certain tourism industry indicators defined by the World Bank for the last available year, 2017:

- International tourism expenditures (It_exp),

- International tourism receipts (It_receipts),

- International tourism number of arrivals (It_arrivals),

- International tourism number of departures (It_depart),

- International tourism receipts for travel items (It_rti),

- Travel and tourism industry GDP (TT_indGDP),

- Travel and tourism industry employment (TT_indempl).

Based on the selected tourism industry indicators one possible answer to the question which Member State has more advanced tourism sector will be provided. This is important because the tourism sector ultimately contributes to the economic growth and development of a given Member State. The descriptive statistics of indicator values is shown in Table 1.

The analysis was conducted in three steps. In the first step criteria weights were obtained using the Entropy Method. In the second step the ranking of the EU member countries was conducted using two multi-criteria methods, while in the third step obtained rank were compared in order to determine whether the application of different multi-criteria methods led to rank inversion. The essence of Entropy Method is that the determination of the criteria weights is based on the uncertainty of the information contained in the decision matrix. Several studies have applied the Entropy Method in the weights' determination during the process of the assessment of tourism development (Kur- 
niawan et al., 2019; Tang, 2015; Zhang et al., 2011; Ostovare \& Shahraki, 2019). The mutual contrast of the individual criterion values represents the basis for generation of a set of criteria weights. Certain steps need to be taken in determining the weight coefficients using entropy methods.

Table 1. Descriptive statistics of tourism industry indicators

\begin{tabular}{|l|c|l|c|c|c|c|}
\hline & N & Metrics & Minimum & Maximum & Mean & Std. Deviation \\
\hline It_exp & 28 & current US\$ & $472,000.00$ & $97,597,000.00$ & $14,820,678.57$ & $22,930,696.75$ \\
\hline It_receipts & 28 & current US\$ & $1,082,000.00$ & $69,894,000.00$ & $17,673,964.28$ & $20,672,114.64$ \\
\hline It_arrivals & 28 & $\begin{array}{l}\text { number of arrivals } \\
\text { (in thousands) }\end{array}$ & $1,046.00$ & $86,861.00$ & $18,665.00$ & $22,934.91$ \\
\hline It_depart & 28 & $\begin{array}{l}\text { number of } \\
\text { departures (in } \\
\text { thousands }\end{array}$ & 573.00 & $92,402.00$ & $16,453.07$ & $21,995.67$ \\
\hline It_rti & 28 & current US\$ & $887,000.00$ & $68,437,000.00$ & $15,783,571.43$ & $19,072,495.35$ \\
\hline $\begin{array}{l}\text { TT_ } \\
\text { indGDP }\end{array}$ & 28 & current US\$ & 795.00 & $138,988.00$ & $26,057.11$ & $41,341.78$ \\
\hline $\begin{array}{l}\text { TT_ } \\
\text { indempl }\end{array}$ & 28 & $\begin{array}{l}\text { number of people } \\
\text { (in thousands) }\end{array}$ & $15,700.00$ & $3,065,300.00$ & $435,657.14$ & $694,352.29$ \\
\hline
\end{tabular}

Source: Authors' calculation

In the first step it is necessary to conduct normalization of attribute $x_{i j}$ :

$$
r_{i j}=\frac{x_{i j}}{\sum_{i=1}^{n} x_{i j}}
$$

And form a normalized decision matrix:

$$
R=\left[\begin{array}{cccc}
r_{11} & r_{12} & \mathrm{~K} & r_{1 m} \\
r_{21} & r_{22} & \mathrm{~K} & r_{2 m} \\
\mathrm{M} & \mathrm{M} & \mathrm{M} & \mathrm{M} \\
r_{n 1} & r_{n 2} & \mathrm{~K} & r_{n m}
\end{array}\right]
$$

In the second step the value of entropy $e_{j}$ should be determined using relation:

$$
e_{j}=-k \sum_{i=1}^{n} r_{i j} \ln r_{i j}, \quad j=1,2, \ldots m
$$

where $k=\frac{1}{\ln n}$ represents a constant.

The third step is focused on the determination of the degree of divergence $d_{j}$ using relation:

$$
d_{j}=1-e_{j}, \quad j=1,2 \ldots . m
$$

where $d_{j}$ represents a measure of the contrast intensity of the criteria $C_{j}$. Higher dispersion amid initial values of a particular criterion points toward a higher value of contrast intensity, thus indicating the greater importance of the observed criterion for a given multi-criteria problem. In contrast, balanced values of a particular criterion point toward smaller relevance of the observed criterion for a given multi-criteria problem.

In the fourth step weight coefficients of criteria are determined using additive normalization relation: 


$$
w_{j}=\frac{d_{j}}{\sum_{j=1}^{m} d_{j}}
$$

As the weights of the criteria are determined directly based on the data from the decision matrix, the subjectivity of the decision-maker is eliminated, and it can be considered that the weight coefficients obtained in this manner are objective.

The Entropy Method was applied to the selected tourism industry indicators and the resulting weight coefficients are presented in the Table 2 . The weight coefficient of each indicator/criterion represents its relative importance in the decision-making model.

Table 2. Weighted coefficients values for analyzed tourism industry indicators

\begin{tabular}{|c|c|c|c|c|c|c|}
\hline \multicolumn{7}{|c|}{ Weighted coefficients } \\
\hline It_exp & It_receipts & It_arrivals & It_depart & It_rti & TT_indGDP & TT_indempl \\
\hline 0.105232009 & 0.195708328 & 0.1982636 & 0.167003 & 0.192848784 & 0.0552117 & 0.085732293 \\
\hline
\end{tabular}

Source: Authors' calculation

In the second step, the multi-criteria assessment was carried out to perform the overall analysis of the EU Member States and their rankings according to tourism industry indicators. Two different multi-criteria techniques were applied:

- Multi-Objective Optimization by Ratio Analysis (MOORA);

- a new Additive Ratio Assessment (ARAS).

Since these two methods have different mathematical approaches, in the next step of the analysis comparative analysis of obtained ranking results of EU Member States will be conducted. The MOORA method starts with a ratio system in which each criterion value of an alternative is compared with a denominator. Denominator is the representative of all alternatives which relate to the given criterion. MOORA is specific because it contains two approaches for determining the most acceptable alternative:

- Ratio System Approach,

- Reference Point Approach.

In this paper, the first approach in using the MOORA method will be applied. The weight/significance of each alternative is determined as the difference between the sum of the revenue and expenditure elements of the weighted normalized decision matrix. During the vector normalization, no expenditures are transformed into revenue attributes.

The MOORA method consists of several steps:

- Setting a target and identifying relevant criterion for evaluating alternatives;

- Based on the available criteria information, correspondingly to the alternatives' performances concerning each of the mentioned criteria, a decision matrix is set;

- MOORA model creation is the process where the performance value of each alternative, with respect to each criterion, is divided by a certain representative measure of the performance value of all alternatives, also with respect to each criterion. It can be seen from the example of the following formula (Madić et al. 2015): 


$$
x_{i j}^{*}=\frac{x_{i j}}{\sqrt{\sum_{i=1}^{m} x_{i j}^{2}}}
$$

where $x_{i j}$ is a dimensionless number between $[0,1]$ and represents the normalized performance of the $i^{\text {th }}$ alternative on $j^{\text {th }}$ criterion.

In the case of revenue criteria, the normalized performance values of the alternatives are summed up, while in the case of the cost criteria the normalized performance values of the alternatives are subtracted. Accordingly, based on the value of the multi-criteria optimization equation, a complete ranking of alternatives can be made. The best-ranked alternative is the one with the highest value of the normalized rating, as presented in the formula (7). In this formula, $n-g$ represent the number of criteria to be maximized and minimized, respectively. Sometimes, decision makers want to give more importance to one criterion compared to the others so the following equation is reformulated by considering the weights of criterion, wherein $w_{j}$ is the weight of $j^{\text {th }}$ criterion.

$$
y_{i j}=\sum_{j=1}^{g} w_{j} x_{i j}^{*}-\sum_{j=g+1}^{n} w_{j} x_{i j}^{*}
$$

The MOORA method is one of the new multi-criteria decision-making methods. In the first step of MOORA application, the elements of the initial decision matrix are normalized, using the vector normalisation method, followed by the optimization procedure (Table 3). Normalized performance values of revenue criteria are added. Then, the same procedure is repeated for the cost criteria. Finally, the sums for cost criteria are subtracted from the sums for revenue criteria.

The results of vector normalization for the analyzed indicators (adjusted by weight coefficients) of the selected countries are in the Normalized decision matrix column. This is followed by an optimization procedure for the values obtained which results are listed in the Optimization column (Table 3).

Table 3. Normalized decision matrix and optimization for data in MOORA method

\begin{tabular}{|l|c|c|c|c|c|c|c|c|}
\hline \multirow{2}{*}{ Countries } & \multicolumn{7}{|c|}{ Normalized decision matrix } \\
& It_exp & It_receipts & It_arrivals & It_depart & It_rti & TTindGDP & TTindempl & \multirow{2}{*}{ Optimization } \\
\hline Austria & 0.4872 & 0.8391 & 0.9237 & 0.6439 & 0.8393 & 0.9468 & 0.9372 & 0.585584953 \\
\hline Belgium & 0.8699 & 0.5149 & 0.2629 & 0.6809 & 0.5165 & 0.3173 & 0.2692 & 0.270915379 \\
\hline Bulgaria & 0.0774 & 0.1752 & 0.2785 & 0.3490 & 0.1699 & 0.0544 & 0.2219 & 0.094172723 \\
\hline Croatia & 0.0529 & 0.4167 & 0.4889 & 0.1077 & 0.4508 & 0.1793 & 0.3363 & 0.291725046 \\
\hline Cyprus & 0.0674 & 0.1171 & 0.1145 & 0.0788 & 0.1292 & 0.0448 & 0.0575 & 0.071868175 \\
\hline Czech Republic & 0.2087 & 0.2881 & 0.3186 & 0.3796 & 0.2878 & 0.1755 & 0.5207 & 0.187942296 \\
\hline Denmark & 0.3647 & 0.2984 & 0.3682 & 0.4540 & 0.3291 & 0.2205 & 0.1585 & 0.183195488 \\
\hline Estonia & 0.0529 & 0.0803 & 0.1017 & 0.0717 & 0.0676 & 0.0298 & 0.0635 & 0.049599938 \\
\hline Finland & 0.2525 & 0.1949 & 0.0997 & 0.5228 & 0.1402 & 0.1510 & 0.1341 & 0.044049514 \\
\hline France & 1.9039 & 2.6174 & 2.7236 & 1.6280 & 2.5200 & 2.9344 & 3.0945 & 1.894000658 \\
\hline Germany & 3.6920 & 2.1036 & 1.1743 & 5.1774 & 1.6500 & 3.7279 & 7.3152 & 1.319562344 \\
\hline Greece & 0.1251 & 0.7048 & 0.8527 & 0.4306 & 0.6964 & 0.4911 & 1.1586 & 0.508999555 \\
\hline Hungary & 0.1125 & 0.3166 & 0.1772 & 1.1373 & 0.2574 & 0.1079 & 0.5274 & 0.019804673 \\
\hline Ireland & 0.2501 & 0.5349 & 0.3242 & 0.4578 & 0.2336 & 0.1961 & 0.1098 & 0.184102528 \\
\hline Italy & 1.0548 & 1.6683 & 1.8266 & 1.7821 & 1.8397 & 3.1472 & 3.6826 & 1.346280425 \\
\hline Latvia & 0.0308 & 0.0405 & 0.0611 & 0.1151 & 0.0366 & 0.0330 & 0.0783 & 0.019654098 \\
\hline
\end{tabular}




\begin{tabular}{|l|c|c|c|c|c|c|c|c|}
\hline \multirow{2}{*}{ Countries } & \multicolumn{9}{|c|}{ Normalized decision matrix } \\
& It_exp & It_receipts & It_arrivals & It_depart & It_rti & TTindGDP & TTindempl & Optimization \\
\hline Lithuania & 0.0496 & 0.0594 & 0.0791 & 0.1139 & 0.0539 & 0.0254 & 0.0601 & 0.030485418 \\
\hline Luxembourg & 0.1147 & 0.0594 & 0.0328 & 0.1010 & 0.1875 & 0.0771 & 0.0375 & 0.056977043 \\
\hline Malta & 0.0179 & 0.0654 & 0.0713 & 0.0321 & 0.0721 & 0.0213 & 0.0628 & 0.043913958 \\
\hline Netherlands & 0.8339 & 0.7622 & 0.5620 & 1.0051 & 0.6536 & 0.4223 & 1.0224 & 0.417502177 \\
\hline Poland & 0.3619 & 0.5274 & 0.5725 & 2.6166 & 0.5274 & 0.2995 & 0.7935 & 0.004100239 \\
\hline Portugal & 0.2136 & 0.7901 & 0.4839 & 0.1230 & 0.7135 & 0.4534 & 0.9288 & 0.494762528 \\
\hline Romania & 0.1599 & 0.1123 & 0.3426 & 1.1180 & 0.1049 & 0.0989 & 0.5310 & -0.008768056 \\
\hline Slovakia & 0.0982 & 0.1122 & 0.0678 & 0.2168 & 0.1212 & 0.0738 & 0.1635 & 0.050978274 \\
\hline Slovenia & 0.0432 & 0.1105 & 0.1124 & 0.1688 & 0.1142 & 0.0507 & 0.0816 & 0.052100689 \\
\hline Spain & 0.8444 & 2.5629 & 2.5645 & 0.9543 & 2.8263 & 2.1045 & 2.2865 & 1.796764963 \\
\hline Sweden & 0.6468 & 0.5320 & 0.2212 & 1.1896 & 0.5866 & 0.3613 & 0.4277 & 0.18709042 \\
\hline UK & 2.7112 & 1.9276 & 1.1806 & 4.1569 & 2.1257 & 2.8239 & 4.0505 & 1.115533992 \\
\hline
\end{tabular}

* Vector normalization of results means that this process includes two steps stages:

vectors' length calculation and dividing each of its components by its length.

Source: Authors' calculation

The ARAS method is also one of the recent date methods which define the most acceptable alternative based on the degree of usefulness of $U_{i}$. The steps in the ARAS method are defined as follows:

- Determination of the reference point $\mathrm{A}_{0}$, based on the decision matrix, using the previously defined formula. The specificity of the ARAS method over others is the introduction of the optimal alternative $A_{0}$. The performance of the optimal alternative is defined based on the preferences of the decision-makers;

- Formation of a normalized matrix, with a normalized reference point value. The normalization used here is either linear or sum method (unlike MOORA method where vector normalization is used);

- Formation of weight normalized matrix and weight normalized reference points;

- In the aggregation process, the values of the weighted normalized matrix for each alternative $A_{i}$ and the reference point $A_{0}$ are summarized. The overall performance index of $S_{i}$ and $S_{0}$ is obtained, where $S_{i}$ is the total performance index of the $i^{t h}$ alternative, and $S_{0}$ is the total performance index of the optimal alternative

$$
S_{i}=\sum_{j=1}^{n} y_{i j}
$$

Calculating the level of usefulness:

$$
U_{i}=\frac{S_{i}}{S_{0}}
$$

- Ranking of alternatives: alternatives are ranked based on their $U_{i}$ values in ascending order, with the highest-ranked alternative being the one with the highest $U_{i}$ value. The best-ranked alternative $A_{A R S}^{*}$, according to the ARAS method, can be defined using the following formula:

$$
A_{A R S}^{*}=\left\{A_{i} \mid A_{i}=\max U_{i}\right\}
$$

The results of the described procedure are presented in Table 4. 
Table 4. Normalized decision matrix results, total performance index and level of usefulness

\begin{tabular}{|c|c|c|c|c|c|c|c|c|c|}
\hline \multirow{2}{*}{ Countries } & \multicolumn{7}{|c|}{ Normalized decision matrix } & \multirow{2}{*}{$S_{i}$} & \multirow{2}{*}{$\mathbf{U}_{\mathrm{i}}$} \\
\hline & It_exp & It_receipts & It_arrivals & It_depart & It_rti & TTindGDP & TTindempl & & \\
\hline Austria & 0.2281 & 253.97 & 0.0139 & 0.0627 & 0.0672 & 0.0019 & 0.0573 & 0.2281 & 32.55 \\
\hline Belgium & 0.1273 & 141.80 & 0.0248 & 0.0385 & 0.0191 & 0.0018 & 0.0352 & 0.1273 & 18.17 \\
\hline Bulgaria & 0.0541 & 60.25 & 0.0022 & 0.0131 & 0.0203 & 0.0035 & 0.0116 & 0.0541 & 7.72 \\
\hline Croatia & 0.1170 & 130.31 & 0.0015 & 0.0312 & 0.0356 & 0.0114 & 0.0308 & 0.1170 & 16.70 \\
\hline Cyprus & 0.0448 & 49.84 & 0.0019 & 0.0088 & 0.0083 & 0.0156 & 0.0088 & 0.0448 & 6.39 \\
\hline Czech Republic & 0.0823 & 91.60 & 0.0059 & 0.0215 & 0.0232 & 0.0032 & 0.0196 & 0.0823 & 11.74 \\
\hline Denmark & 0.0898 & 100.00 & 0.0104 & 0.0223 & 0.0268 & 0.0027 & 0.0225 & 0.0898 & 12.82 \\
\hline Estonia & 0.0379 & 42.16 & 0.0015 & 0.0060 & 0.0074 & 0.0171 & 0.0046 & 0.0379 & 5.40 \\
\hline Finland & 0.0448 & 49.84 & 0.0072 & 0.0146 & 0.0073 & 0.0024 & 0.0096 & 0.0448 & 6.39 \\
\hline France & 0.7007 & 780.28 & 0.0543 & 0.1957 & 0.1983 & 0.0008 & 0.1719 & 0.7007 & 100.00 \\
\hline Germany & 0.6018 & 670.14 & 0.1052 & 0.1573 & 0.0855 & 0.0002 & 0.1126 & 0.6018 & 85.89 \\
\hline Greece & 0.1896 & 211.10 & 0.0036 & 0.0527 & 0.0621 & 0.0029 & 0.0475 & 0.1896 & 27.05 \\
\hline Hungary & 0.0662 & 73.72 & 0.0032 & 0.0237 & 0.0129 & 0.0011 & 0.0176 & 0.0662 & 9.45 \\
\hline Ireland & 0.0935 & 104.16 & 0.0071 & 0.0400 & 0.0236 & 0.0027 & 0.0159 & 0.0935 & 13.35 \\
\hline Italy & 0.5038 & 560.99 & 0.0301 & 0.1247 & 0.1330 & 0.0007 & 0.1255 & 0.5038 & 71.90 \\
\hline Latvia & 0.0229 & 25.54 & 0.0009 & 0.0030 & 0.0044 & 0.0107 & 0.0025 & 0.0229 & 3.27 \\
\hline Lithuania & 0.0272 & 30.26 & 0.0014 & 0.0044 & 0.0058 & 0.0108 & 0.0037 & 0.0272 & 3.88 \\
\hline Luxembourg & 0.0366 & 40.81 & 0.0033 & 0.0044 & 0.0024 & 0.0122 & 0.0128 & 0.0366 & 5.23 \\
\hline Malta & 0.0548 & 61.06 & 0.0005 & 0.0049 & 0.0052 & 0.0383 & 0.0049 & 0.0548 & 7.83 \\
\hline Netherlands & 0.1845 & 205.47 & 0.0238 & 0.0570 & 0.0409 & 0.0000 & 0.0446 & 0.1845 & 26.33 \\
\hline Poland & 0.1416 & 157.71 & 0.0103 & 0.0394 & 0.0417 & 0.0005 & 0.0360 & 0.1416 & 20.21 \\
\hline Portugal & 0.1767 & 196.74 & 0.0061 & 0.0591 & 0.0352 & 0.0100 & 0.0487 & 0.1767 & 25.21 \\
\hline Romania & 0.0538 & 59.95 & 0.0046 & 0.0084 & 0.0249 & 0.0011 & 0.0072 & 0.0538 & 7.68 \\
\hline Slovakia & 0.0331 & 36.82 & 0.0028 & 0.0084 & 0.0049 & 0.0057 & 0.0083 & 0.0331 & 4.72 \\
\hline Slovenia & 0.0345 & 38.38 & 0.0012 & 0.0083 & 0.0082 & 0.0073 & 0.0078 & 0.0345 & 4.92 \\
\hline Spain & 0.6545 & 728.84 & 0.0241 & 0.1916 & 0.1867 & 0.0013 & 0.1928 & 0.6545 & 93.41 \\
\hline Sweden & 0.1257 & 140.02 & 0.0184 & 0.0398 & 0.0161 & 0.0010 & 0.0400 & 0.1257 & 17.95 \\
\hline UK & 0.5420 & 603.57 & 0.0773 & 0.1441 & 0.0859 & 0.0003 & 0.1450 & 0.5420 & 77.35 \\
\hline
\end{tabular}

* Construction of the linear normalization results: $\mathrm{y}=\left(\mathrm{x}-\mathrm{x}_{\min }\right) /\left(\mathrm{x}_{\max }-\mathrm{x}_{\min }\right)$, where $\mathrm{y}$ is the normalization value, $x$ is the original value, $x_{\max }$ is the maximum original value and $x_{\min }$ is the minimum original value.

Source: Authors' calculation

After forming the normalized decision matrix and applying linear normalization to the values of the selected countries indicators (adjusted by weight coefficients) in the Normalized decision matrix column are obtained values. The next step in the ARAS method is to determine the value of the total performance index for each of the alternatives whose values are shown in the $\mathrm{Si}$ column. The last step of the ARAS method is to calculate the utility level Ui (the quotient of the performance index of the i-th alternative and the total performance index of optimal alternative) which results are shown in Table 4.

\section{COMPARATIVE ANALYSIS OF THE RESULTS}

The results of the conducted multi-criteria assessment using MOORA and ARAS method (both based on different mathematical patterns applied for ranking of the alternatives) are presented in Table 5. According to those results, based on the current analysed indicators, France is first on the list of ranking EU Member States. This fact, doesn't implies explicitly that France is the best example or optimal solution, but it is sure that the French travel industry has well balanced values of analyzed indicators. So, it could be a suggested sustainable model for other selected countries. 
Table 5. Ranking EU member states according to MOORA and ARAS methods

\begin{tabular}{|c|c|c|c|c|}
\hline \multirow{2}{*}{$\begin{array}{l}\text { MOORA } \\
\text { France }\end{array}$} & \multirow[b]{2}{*}{1.8940} & \multirow{2}{*}{$\begin{array}{c}\text { Rank } \\
1 .\end{array}$} & \multicolumn{2}{|l|}{ ARAS } \\
\hline & & & France & 100.00 \\
\hline Spain & 1.7968 & 2. & Spain & 93.41 \\
\hline Italy & 1.3463 & 3. & Germany & 85.89 \\
\hline Germany & 1.3196 & 4. & UK & 77.35 \\
\hline UK & 1.1155 & 5. & Italy & 71.90 \\
\hline Austria & 0.5856 & 6. & Austria & 32.55 \\
\hline Greece & 0.5090 & 7. & Greece & 27.05 \\
\hline Portugal & 0.4948 & 8. & Netherlands & 26.33 \\
\hline Netherlands & 0.4175 & 9. & Portugal & 25.21 \\
\hline Croatia & 0.2917 & 10. & Poland & 20.21 \\
\hline Belgium & 0.2709 & 11. & Belgium & 18.17 \\
\hline Czech Republic & 0.1879 & 12. & Sweden & 17.95 \\
\hline Sweden & 0.1871 & 13. & Croatia & 16.70 \\
\hline Ireland & 0.1841 & 14. & Ireland & 13.35 \\
\hline Denmark & 0.1832 & 15. & Denmark & 12.82 \\
\hline Bulgaria & 0.0942 & 16. & Czech Republic & 11.74 \\
\hline Cyprus & 0.0719 & 17. & Hungary & 9.45 \\
\hline Luxembourg & 0.0570 & 18. & Malta & 7.83 \\
\hline Slovenia & 0.0521 & 19. & Bulgaria & 7.72 \\
\hline Slovakia & 0.0510 & 20. & Romania & 7.68 \\
\hline Estonia & 0.0496 & 21. & Cyprus & 6.39 \\
\hline Finland & 0.0440 & 22. & Finland & 6.39 \\
\hline Malta & 0.0439 & 23. & Estonia & 5.40 \\
\hline Lithuania & 0.0305 & 24. & Luxembourg & 5.23 \\
\hline Hungary & 0.0198 & 25. & Slovenia & 4.92 \\
\hline Latvia & 0.0197 & 26. & Slovakia & 4.72 \\
\hline Poland & 0.0041 & 27. & Lithuania & 3.88 \\
\hline Romania & -0.0088 & 28. & Latvia & 3.27 \\
\hline
\end{tabular}

Source: Authors' calculation

Nevertheless, the results of the applied multi-criteria decision-making techniques indicate that, even though the same alternative is the best according to both methods, there are differences in ranks of other countries in the sample. These differences may be caused by the differences in the process of normalization of the decision matrix. As stated, the MOORA method uses vector normalization while the ARAS method uses linear normalization. The differences can best be seen at the bottom of the table. According to MOORA method, the worst-ranked country is Romania, while according to ARAS method Latvia is at the bottom of the list. Conversely, MOORA method places Latvia at the $26^{\text {th }}$ position, while ARAS method enlists Romania at $20^{\text {th }}$ position. It is also interesting to analyse ranking patterns at the top of the table. Consistent with the results of the MOORA method, the ranking pattern can be represented as France $>$ Spain $>$ Italy, while the ranking pattern with the ARAS method is France $>$ Spain $>$ Germany.

With the intention of examination of the interrelation amid the mentioned EU Member States rankings, it is necessary to perform correlation analysis. Comparative analysis of the ranking results is conducted using Spearman's rank-order correlation. Spearman's rank-order correlation is used to examine the strength of the relationship and the direction of the association between the obtained rank values for both methods. The correlation analysis is conducted in SPSS program, and it can be concluded that there is an extremely strong and positive, statistically significant correlation between the two variables (MOORA_rank and ARAS_rank) with the Spearman's rho value of 0.829 (Table 6). 
Table 6. Spearman's rank-order correlation for MOORA and ARAS ranking values

\begin{tabular}{|c|c|c|c|c|}
\hline & & & MOORA_rank & ARAS_rank \\
\hline \multirow{6}{*}{ Spearman's rho } & \multirow{3}{*}{ MOORA_rank } & $\begin{array}{l}\text { Correlation } \\
\text { Coefficient }\end{array}$ & 1.000 & $.829^{* *}$ \\
\hline & & Sig. (2-tailed) & . & .000 \\
\hline & & $\mathrm{N}$ & 28 & 28 \\
\hline & \multirow{3}{*}{ ARAS_rank } & $\begin{array}{c}\text { Correlation } \\
\text { Coefficient } \\
\end{array}$ & $.829^{* *}$ & 1.000 \\
\hline & & Sig. (2-tailed) & .000 & . \\
\hline & & $\mathrm{N}$ & 28 & 28 \\
\hline
\end{tabular}

** Correlation is significant at the 0.01 level (2-tailed).

Source: Authors' calculation

Hence, the research hypothesis is confirmed, the application of different multi-criteria decision-making techniques on the same dataset and with the same criteria weights doesn't lead to rank-inversion.

\section{FUTURE RESEARCH DIRECTIONS}

Further research in this area may be directed towards examining the impact of different weighting methods on the ranking of alternatives. It is also possible to consider the inclusion of some other tourism indicators.

\section{CONCLUSION}

Tourism is a sector of great importance for the national economy, especially given its multiplier effects. In addition to promoting economic growth and the development of the national economy, tourism has numerous direct and indirect impacts. The direct impact is reflected in increasing employment, balancing the balance of payments, as well as improving the overall standard of living. Also, tourism affects other activities such as agriculture, construction and the like. Therefore, adequate assessment of the level of tourism development of a country is very important. One of the benefits of the assessment is the determination of the comparative position of one country concerning other countries. Nevertheless, tourism represents a sector whose effects cannot be easily quantified. Various methodologies have been applied to evaluate tourism development on different levels, wherein each of the proposed methodologies has some advantages and disadvantages.

With the intention of offering one possible approach for the assessment of tourism development of EU countries, this paper applies two multi-criteria decision-making techniques and provides a comparative analysis of the obtained results. Assessment of tourism development was conducted using three-step analysis. In the first step, the Entropy method was applied to the set of selected tourism industry indicators. In the second step, two multi-criteria decision-making methods (MOORA and ARAS) have been applied to obtain ranking results. In the third step, comparative analysis of results was conducted to determine whether the application of different multi-criteria methods led to rank inversion. The results of both applied methods indicate that Western and Southern European countries have the most developed tourism sector, mainly France, Spain and Italy. Additionally, the results of comparative analysis indicate that the application of different multi-criteria decision-making techniques on the same dataset and with the same criteria weights doesn't lead to rank-inversion. 
Our study faces some limitations. The results of the research largely depend on the indicators selected, and the application of some other indicators may lead to different results. Additionally, the criteria weights have a big influence on the rankings of alternatives, hence, the application of other methods of weights determination may lead to rank inversion.

\section{ACKNOWLEDGEMENT}

The paper is a part of the research done within the projects 179066 and 43014, funded by the Ministry of Education, Science and Technological Development of the Republic of Serbia.

\section{REFERENCES}

Assaf, A. G. (2012). Benchmarking the Asia Pacific tourism industry: A Bayesian combination of DEA and stochastic frontier. Tourism Management, 33(5), 1122-1127.

Assaf, A. G., \& Josiassen, A. (2016). Frontier analysis: A state-of-the-art review and meta-analysis. Journal of Travel Research, 55(5), 612-627.

Baggio, R. (2019). Measuring tourism: methods, indicators, and needs. In The Future of Tourism (pp. 255-269). Springer, Cham.

Bahar, O., \& Kozak, M. (2007). Advancing destination competitiveness research: Comparison between tourists and service providers. Journal of Travel \& Tourism Marketing, 22(2), 61-71.

Balaguer, J., \& Cantavella-Jorda, M. (2002). Tourism as a long-run economic growth factor: the Spanish case. Applied economics, 34(7), 877-884.

Barros, C. P., Botti, L., Peypoch, N., Robinot, E., \& Solonandrasana, B. (2011). Performance of French destinations: Tourism attraction perspectives. Tourism Management, 32(1), 141-146.

Blancas, F. J., Lozano-Oyola, M., \& González, M. (2015). A European sustainable tourism labels proposal using a composite indicator. Environmental Impact Assessment Review, 54, 39-54.

Botti, L., \& Peypoch, N. (2013). Multi-criteria ELECTRE method and destination competitiveness. Tourism Management Perspectives, 6, 108-113.

Bornhorst, T., Ritchie, J. B., \& Sheehan, L. (2010). Determinants of tourism success for DMOs \& destinations: An empirical examination of stakeholders' perspectives. Tourism management, 31(5), 572-589.

Bošković, T. (2009). Tourism as a factor of economic development (In Serbian). Škola biznisa, 2, $23-28$.

Brida, J. G., Cortes-Jimenez, I., \& Pulina, M. (2016). Has the tourism-led growth hypothesis been validated? A literature review. Current Issues in Tourism, 19(5), 394-430.

Carrillo, M., \& Jorge, J. M. (2017). Multidimensional analysis of regional tourism sustainability in Spain. Ecological Economics, 140, 89-98.

Chen, C. F. (2007). Applying the stochastic frontier approach to measure hotel managerial efficiency in Taiwan. Tourism Management, 28(3), 696-702.

Chen, C. M., Chen, S. H., \& Lee, H. T. (2011). The destination competitiveness of Kinmen's tourism industry: exploring the interrelationships between tourist perceptions, service performance, customer satisfaction and sustainable tourism. Journal of Sustainable Tourism, 19(2), 247-264.

Chen, C. M., Chen, S. H., Lee, H. T., \& Tsai, T. H. (2016). Exploring destination resources and competitiveness-A comparative analysis of tourists' perceptions and satisfaction toward an island of Taiwan. Ocean \& Coastal Management, 119, 58-67.

Choi, H. C., \& Sirakaya, E. (2006). Sustainability indicators for managing community tourism. Tourism management, 27(6), 1274-1289. 
Clement, H. G. (1961). The Future of Tourism in the Pacific and the Far East. A Report Prepared Under Contract with the US Dept. of Commerce and Co-sponsored by the Pacific Area Travel Association, Written by Harry G. Clement, Vice President. US Department of Commerce, Bureau of Foreign Commerce.

Cracolici, M. F., \& Nijkamp, P. (2006). Competition among Tourist Destinations: An Application of Data Envelopment. Tourism and regional development: New pathways, 133.

Cracolici, M. F., Nijkamp, P., \& Rietveld, P. (2008). Assessment of tourism competitiveness by analysing destination efficiency. Tourism Economics, 14(2), 325-342.

Cracolici, M. F., \& Nijkamp, P. (2009). The attractiveness and competitiveness of tourist destinations: A study of Southern Italian regions. Tourism management, 30(3), 336-344.

Croes, R., \& Kubickova, M. (2013). From potential to ability to compete: Towards a performance-based tourism competitiveness index. Journal of Destination Marketing \& Management, 2(3), 146-154.

Crouch, G. I., \& Ritchie, J. B. (2005). Application of the analytic hierarchy process to tourism choice and decision making: A review and illustration applied to destination competitiveness. Tourism Analysis, 10(1), 17-25.

Cuccia, T., Guccio, C., \& Rizzo, I. (2017). UNESCO sites and performance trend of Italian regional tourism destinations: A two-stage DEA window analysis with spatial interaction. Tourism Economics, 23(2), 316-342.

Del Vasto-Terrientes, L., Fernández-Cavia, J., Huertas, A., Moreno, A., \& Valls, A. (2015). Official tourist destination websites: Hierarchical analysis and assessment with ELECTRE-III-H. Tourism Management Perspectives, 15, 16-28.

Dupeyras, A. \& N. MacCallum (2013). Indicators for Measuring Competitiveness in Tourism: A Guidance Document, OECD Tourism Papers, 2013/02, OECD Publishing.

http://dx.doi.org/10.1787/5k47t9q2t923-en

Dwyer, L., \& Kim, C. (2003). Destination competitiveness: determinants and indicators. Current issues in tourism, 6(5), 369-414.

Dwyer, L., Cvelbar, L. K., Edwards, D., \& Mihalic, T. (2012). Fashioning a destination tourism future: The case of Slovenia. Tourism Management, 33(2), 305-316.

ETIS (2016) https://ec.europa.eu/growth/sectors/tourism/offer/sustainable/indicators_en

Fernández, J. I. P., \& Rivero, M. S. (2009). Measuring tourism sustainability: proposal for a composite index. Tourism Economics, 15(2), 277-296.

Garrod, B., \& Fyall, A. (2005). Revisiting Delphi: the Delphi technique in tourism research. Tourism research methods: Integrating theory with practice, 85 .

Ghamgosar, M., Haghyghy, M., Mehrdoust, F., \& Arshad, N. (2011). Multicriteria decision making based on analytical hierarchy process (AHP) in GIS for tourism. Middle-East Journal of Scientific Research, 10(4), 501-507.

Goeldner, C. R., \& Ritchie, J. B. (2007). Tourism principles, practices, philosophies. John Wiley $\&$ Sons.

Hu, J. L., Chiu, C. N., Shieh, H. S., \& Huang, C. H. (2010). A stochastic cost efficiency analysis of international tourist hotels in Taiwan. International Journal of Hospitality Management, 29(1), 99-107.

Huang, J. H., \& Peng, K. H. (2012). Fuzzy Rasch model in TOPSIS: A new approach for generating fuzzy numbers to assess the competitiveness of the tourism industries in Asian countries. Tourism Management, 33(2), 456-465.

Kurniawan, F., Adrianto, L., Bengen, D. G., \& Prasetyo, L. B. (2019). The social-ecological status of small islands: An evaluation of island tourism destination management in Indonesia. Tourism Management Perspectives, 31, 136-144. 
Kwok, P. K., \& Lau, H. Y. (2019). Hotel selection using a modified TOPSIS-based decision support algorithm. Decision Support Systems, 120, 95-105.

Lee, C. C., \& Chang, C. P. (2008). Tourism development and economic growth: A closer look at panels. Tourism Management, 29(1), 180-192.

Lopes, A. P. F., Muñoz, M. M., \& Alarcón-Urbistondo, P. (2018). Regional tourism competitiveness using the PROMETHEE approach. Annals of Tourism Research, 73, 1-13.

Madić, M., Petković, D.Lj. \& Radovanović, M. (2015). Non-conventional machining processes selection using multi-objective optimization on the basis of ratio analysis method, Journal of Engineering Science and Technology, 10(11), 1441-1452, School of Engineering, Taylor's University.

Mendola, D., \& Volo, S. (2017). Building composite indicators in tourism studies: Measurements and applications in tourism destination competitiveness. Tourism Management, 59, 541-553.

Miller, G. (2001). The development of indicators for sustainable tourism: results of a Delphi survey of tourism researchers. Tourism management, 22(4), 351-362.

Nardo, M., Saisana, M., Saltelli, A., \& Tarantola, S. (2005). Tools for composite indicators building. European Comission, Ispra, 15, 19-20.

Niavis, S., \& Tsiotas, D. (2019). Assessing the tourism performance of the Mediterranean coastal destinations: A combined efficiency and effectiveness approach. Journal of Destination Marketing \& Management, 14, 100379.

Nilashi, M., Samad, S., Manaf, A. A., Ahmadi, H., Rashid, T. A., Munshi, A., ... \& Ahmed, O. H. (2019). Factors influencing medical tourism adoption in Malaysia: A DEMATEL-Fuzzy TOPSIS approach. Computers \& Industrial Engineering, 137, 106005.

OECD (2019). Indicators Measuring Competitiveness in Tourism. https://www.oecd.org/cfe/tourism/Indicators\%20for\%20Measuring\%20Competitiveness $\% 20 \mathrm{in} \% 20$ Tourism.pdf

Oh, C. O. (2005). The contribution of tourism development to economic growth in the Korean economy. Tourism management, 26(1), 39-44.

Ostovare, M., \& Shahraki, M. R. (2019). Evaluation of hotel websites using the multicriteria analysis of PROMETHEE and GAIA: Evidence from the five-star hotels of Mashhad. Tourism Management Perspectives, 30, 107-116.

Pablo-Romero, M. D. P., \& Molina, J. A. (2013). Tourism and economic growth: A review of empirical literature. Tourism Management Perspectives, 8, 28-41.

Perez, V., Guerrero, F., González, M., Perez, F., \& Caballero, R. (2013). Composite indicator for the assessment of sustainability: The case of Cuban nature-based tourism destinations. Ecological Indicators, 29, 316-324.

Poudel, S., Nyaupane, G. P., \& Budruk, M. (2016). Stakeholders' perspectives of sustainable tourism development: A new approach to measuring outcomes. Journal of Travel Research, 55(4), 465-480.

Pratt, S. (2015). The economic impact of tourism in SIDS. Annals of Tourism Research, 52, 148-160.

Pulido-Fernández, J. I., \& Rodríguez-Díaz, B. (2016). Reinterpreting the World Economic Forum's global tourism competitiveness index. Tourism Management Perspectives, 20, 131-140.

Ritchie, J. B., \& Crouch, G. I. (2003). The competitive destination: A sustainable tourism perspective. Cabi.

Ryan, C., \& Huyton, J. (2000). Who is interested in Aboriginal tourism in the Northern Territory, Australia? A cluster analysis. Journal of Sustainable Tourism, 8(1), 53-88.

Shi, C. Y., Zhang, J., \& You, H. M. (2008). Structural Equation Model for tourism destination competitiveness from tourists' perception perspectives [J]. Geographical Research, 3(27), 703-714. 
Swarbrooke, J. (1999). Sustainable tourism management. Cabi.

Spencer, D. M., \& Holecek, D. F. (2007). Basic characteristics of the fall tourism market. Tourism management, 28(2), 491-504.

Tang, Z. (2015). An integrated approach to evaluating the coupling coordination between tourism and the environment. Tourism Management, 46, 11-19.

UNWTO (2011). Tourism towards 2030. Global overview. http://cf.cdn.unwto.org/sites/all/files/pdf/unwto_2030_ga_2011_korea_1.pdf

UNWTO (2016) Tourism Highlights: 2016 Edition. https://www.e-unwto.org/doi/pdf/10.18111/9789284418145

UNWTO (2018). Tourism Highlights: 2018 Edition. https://www.e-unwto.org/doi/pdf/10.18111/9789284419876

UNWTO (2019a) International Tourism Highlights, 2019 Edition. https://www.e-unwto.org/doi/pdf/10.18111/9789284421152

UNWTO (2019b) International Tourist Arrivals Reach 1.4 billion Two Years Ahead of Forecasts https://www2.unwto.org/press-release/2019-01-21/international-tourist-arrivals-reach-14-billion-two-years-ahead-forecasts

Vareiro, L. M. D. C., Remoaldo, P. C., \& Cadima Ribeiro, J. A. (2013). Residents' perceptions of tourism impacts in Guimarães (Portugal): a cluster analysis. Current Issues in Tourism, 16(6), 535-551.

Wang, Y., Lee, W., \& Wong, C. (2007). Productivity and efficiency analysis of international tourist hotels in Taiwan: An application of the stochastic frontier approach. Taiwan Economic Review, 35(1), 55.

WEF (2019) https://www.weforum.org/reports/the-travel-tourism-competitiveness-report-2019

World Bank (2019). International tourism, number of arrivals. https://data.worldbank.org/indicator/st.int.arvl

World Tourism Organization (2001). Tourism Satellite Account: Recommended Methodological Framework, https://unstats.un.org/unsd/publication/SeriesF/SeriesF_80E.pdf

WTTC (2019) Travel \& Tourism: Economic Impact. World Travel \& Tourism Council. https://www.wttc.org/-/media/files/reports/economic-impact-research/regions-2019/ world2019.pdf

Yoon, Y. (2002). Development of a structural model for tourism destination competitiveness from stakeholders' perspectives (Doctoral dissertation, Virginia Tech).

Zaman, K., Shahbaz, M., Loganathan, N., \& Raza, S. A. (2016). Tourism development, energy consumption and Environmental Kuznets Curve: Trivariate analysis in the panel of developed and developing countries. Tourism Management, 54, 275-283.

Zhang, H., Gu, C. L., Gu, L. W., \& Zhang, Y. (2011). The evaluation of tourism destination competitiveness by TOPSIS \& information entropy-A case in the Yangtze River Delta of China. Tourism Management, 32(2), 443-451.

Zhong, L., Deng, J., Song, Z., \& Ding, P. (2011). Research on environmental impacts of tourism in China: Progress and prospect. Journal of environmental management, 92(11), 2972-2983.

Zhou, Y., Maumbe, K., Deng, J., \& Selin, S. W. (2015). Resource-based destination competitiveness evaluation using a hybrid analytic hierarchy process (AHP): The case study of West Virginia. Tourism Management Perspectives, 15, 72-80. 